$\mathbf{R}_{\text {ESEARCh }} \mathbf{P}_{\text {APER }} \longrightarrow$ FOOD SCIENCE

Visit us : www.researchjournal.co.in Volume 9 | Issue 2 | October, 2018 | 327-335

DOI : $10.15740 / \mathrm{HAS} / \mathrm{FSRJ} / 9.2 / 327-335$

\title{
Germination and fermentation effect on compositional and functional characteristics of sorghum flour
}

\author{
A.V. Gawande, K.P. Babar and D.T. Bornare
}

\begin{abstract}
Sorghum popularly known as "Jowar" in India. This study was conducted to explore the impact of malting and fermentation on compositional and functional properties of sorghum flour. This investigation was carried out on Parbhani moti (SPV 1411) and Phule revati (SPV 1830) sorghum varieties. Furthermore, there are four sorghum flour sample prepared viz., regular, malted, fermented and malted fermented flour of each variety. From results it is observed that malting and fermentation increases the moisture content from 12.18 per cent to 12.61 per cent and protein content from 9.2 per cent to 13.23 per cent. In other hand it leads to decrease the ash content of the sorghum flour. The highest fibre content is found in the fermented flour $(2.23 \%)$ than that of malted flour (1.88 \%) in Parbhani moti variety. In term of Phule revati, fibre content $(2.54 \%)$ is found higher on malted flour. Also, the water absorption increases in the malted and fermented flour as the bulk density decreases.
\end{abstract}

Key Words : Malting, Fermentation, Protein content, Bulk density

How to cite this article : Gawande, A.V., Babar, K.P. and Bornare, D.T. (2018). Germination and fermentation effect on compositional and functional characteristics of sorghum flour. Food Sci. Res. J., 9(2): 327-335, DOI : 10.15740/HAS/FSRJ/9.2/327-335. Copyright@ 2018: Hind Agri-Horticultural Society. 